\title{
Methylation of inorganic mercury by methylcobalamin in aquatic systems
}

\author{
Baowei Chen, Thanh Wang, Yongguang Yin, Bin He and Guibin Jiang*
}

State Key Laboratory of Environmental Chemistry and Ecotoxicology, Research Center of Eco-Environmental Sciences, Chinese Academy of Sciences, PO Box 2871, Beijing 100085, People's Republic of China

Received 7 November 2006; Revised 10 January 2007; Accepted 26 January 2007

\begin{abstract}
The methylation of inorganic $\mathrm{Hg}$ (II) by methylcobalamin in aquatic systems was studied using high-performance liquid chromatography coupled with UV-digestion cold vapor atomic fluorescence spectrometry (HPLC-UV-CV AFS). Monomethylmercury (MMC) could be positively identified as the reaction product in the aqueous solution. The salinity and $\mathrm{pH}$ of the aquatic system have great effects on the formation of MMC, because they could change the species of the reactants in the solution. From an electrophile reaction point of view, salinity and $\mathrm{pH}$ alter the electron density of the methyl donor and the electrophilicity of metal ion in the reaction system. This methylation of inorganic $\mathrm{Hg}$ (II) is shown to be possible even in highly saline solutions, which indicates its importance in aquatic environments. Kinetic experiments showed that the methylation reaction was fast and first-order for $\mathrm{Hg}$ (II). The first-order reaction rate was determined to be 0.00612 and $0.000287 \mathrm{~min}^{-1}$ for $\mathrm{pH} 5.0$ and 1.5 , respectively. It is suggested that this methylation could occur in the absence of enzymes, in which $\mathrm{Hg}$ (II) acts as an electrophile to attack methylcobalamin with a subsequent transfer of carbanion methyl group to the higher oxidized state of $\mathrm{Hg}(\mathrm{II})$. Copyright $\odot 2007 \mathrm{John}$ Wiley \& Sons, Ltd.
\end{abstract}

KEYWORDS: methylation; inorganic mercury; methylmercury; methylcobalamin; $\mathrm{pH}$; salinity; electrophile reaction

\section{INTRODUCTION}

Mercury compounds have long been of great public concern because of their adverse effect on wildlife and humans. It is well known that the toxicity of mercury compounds depends on their species, which include inorganic, methyl, ethyl and phenylmercury. Amongst these compounds, methylmercury is the most toxic form in the environment. One famous case of severe methylmercury poisoning occurred in Minamata, Japan, which was caused by the consumption of seafood contaminated with methylmercury compounds discharged from a chemical plant in the 1950s and 1960s.

Methylation of elements such as $\mathrm{Hg}$, As and $\mathrm{Sn}$ is an important transformation and transportation pathway

\footnotetext{
*Correspondence to: Guibin Jiang, State Key Laboratory of Environmental Chemistry and Ecotoxicology, Research Center of Ecoenvironmental Sciences, Chinese Academy of Sciences, Beijing 100085, China.

E-mail: gbjiang@rcees.ac.cn

Contract/grant sponsor: National Natural Science Foundation of China; Contract/grant number: 20477053.

Contract/grant sponsor: National Basic Research Program of China; Contract/grant number: 2003CB415001 and 2005CB422206.
}

of elements in the environment, and has been widely studied. ${ }^{1}$ Natural conversion from inorganic mercury to methylmercury was first demonstrated by Jensen and Jernelov. $^{2}$ There exist two methylation pathways of inorganic mercury: the biotic process and the abiotic process in the aquatic environment. ${ }^{3}$ Although many scientists have provided evidence for abiotic methylation of mercury in the environment, ${ }^{4,5}$ it is widely accepted that biotic methylation accounts for most or all methylation in the environment, especially by sulfate-reducing bacteria (SRB) ${ }^{6,7}$ However, the relative importance of abiotic methylation of inorganic $\mathrm{Hg}$ (II) should not be neglected. ${ }^{3}$

Chemical methylation of inorganic $\mathrm{Hg}$ (II) can occur only if suitable methyl donors exist in the environment. Nagase demonstrated that inorganic $\mathrm{Hg}$ (II) can be methylated by fulvic and humic acids, which are large organic components of dissolved organic matter. ${ }^{5}$ It is also possible that inorganic mercury can be methylated by acetic acid, propionic acid and ethanol in aquatic environments under the irradiation of sunlight or ultraviolet light., Transmethyl reaction between inorganic $\mathrm{Hg}$ (II) and other methylmetals, such as the methyl transfer from methyltin 
to inorganic $\mathrm{Hg}(\mathrm{II})$, have also been shown to be possible in aquatic environments. ${ }^{10}$ Moreover, Wood demonstrated the formation of mono- and dimethylmercury from $\mathrm{Hg}$ (II) in cell-free extracts of a pure culture of a methanogenic bacterium using substrate concentrations of methylcobalamin under strict anaerobic conditions. Methyl transfer from methylcobalamin to inorganic $\mathrm{Hg}$ (II) was suggested as the most probable mechanism. ${ }^{11}$ However, it is debated whether this methyl transfer reaction is an enzymatic or non-enzymatic processes. ${ }^{12,13}$ Its importance in the aquatic environment, particularly in the presence of $\mathrm{Cl}^{-}$, has not been established. ${ }^{7}$ Elucidation of the methyl transfer mechanism from methylcobalamin to inorganic $\mathrm{Hg}$ (II) was further complicated by conflicting conclusions from Bertilsson and Imura, which respectively stated that monomethylmercury or dimethylmercury is the initial product of this methylation reaction. ${ }^{13,14}$ Moreover, experimental results from Craig and Morton suggested that monomethylmercury (MMC) was the initial product, and the thermodynamic parameters of the methylation reaction could thereafter be calculated. ${ }^{15}$

In our paper, the methylation of inorganic $\mathrm{Hg}$ (II) by methylcobalamin in aquatic systems was investigated using a sensitive HPLC-UV-CV AFS system. The methylation reaction was carried out under different $\mathrm{pH}$ and salinity conditions. The effects of these two factors on the methylation reaction were emphasized and further explained in detail. A probable mechanism for the methylation of inorganic $\mathrm{Hg}$ (II) by methylcobalamin was proposed.

\section{EXPERIMENTAL}

\section{Reagent and standards}

All reagents were obtained commercially and used without further purification unless otherwise stated. De-ionized water (EASY Pure LF, Barnstead Co., USA) was used throughout. Methylcobalamin $\left(\mathrm{CH}_{3} \mathrm{~B}_{12} ; 99.5 \%\right)$ was purchased from Phentex Corp. (USA). Methylmercury chloride and mercury chloride were obtained from Merck-Schuchardt (Germany). Stock solutions of methylmercury chloride $\left(1 \mathrm{mg} \mathrm{ml}^{-1}\right.$ as $\mathrm{Hg}$ ) were prepared by dissolving appropriate amounts of methylmercury chloride in methanol and stored at $4{ }^{\circ} \mathrm{C}$ in darkness. Working solutions diluted with de-ionized water for analysis were prepared daily prior to use.

\section{Analytical method}

An HPLC-UV-CV AFS system was used to detect mercury species in aqueous solutions. A quaternary pump (P680 HPLC Pump, Dionex, USA) equipped with a Rheodyne Model 7715i injector valve (Rheodyne, Cotati, CA, USA) and a $20 \mu \mathrm{l}$ sample loop was used for sample introduction. An Agilent Zorbax ODS column $(150 \times 4.6 \mathrm{~mm}$ i.d., $5 \mu \mathrm{m})$ was used to separate the mercury species. The effluent from the HPLC system was delivered to an $8 \mathrm{~m}$ PTFE digestion coil (i.d. $0.8 \mathrm{~mm}$ ) wrapped around an $8 \mathrm{~W}$ UV lamp, where decomposition of methylmercury to inorganic mercury took place, with $0.5 \% \mathrm{~K}_{2} \mathrm{~S}_{2} \mathrm{O}_{8}$ in $10 \% \mathrm{HCl}$ converged by a peristaltic pump as the oxidant. Following the introduction of a $0.5 \% \mathrm{KBH}_{4}$ in $0.2 \% \mathrm{KOH}$ solution, cold vapors of mercury were produced and separated in the gas-liquid separator. Thereafter, it was carried to the detector by an argon stream, and detected with an AFS-610A non-dispersive atomic fluorescence spectrometer (Beijing Rayleigh Analytical Instrument Co., China). The spectrometer was equipped with a high-intensity hollow cathode mercury lamp at $253.7 \mathrm{~nm}$ line source (Beijing Tiangong Analytical Instrument Factory, China), running at $280 \mathrm{~V}$ of PMT voltage and $40 \mathrm{~mA}$ of lamp current. A personal computer with an AFS-610A software was used as a work station. The column, T-cross valve and the gas-liquid separator were connected by a PTFE tube. Detailed experiment conditions for HPLC-UV-CV-AFS are listed in Table 1.

\section{Experimental design}

In general, the methylation reaction of inorganic mercury with methylcobalamin took place in darkness at about $30^{\circ} \mathrm{C}$ using $10 \mathrm{ml}$ aqueous solution in $20 \mathrm{ml}$ glass tubes. Stock solution of $100 \mathrm{mg} \mathrm{L}^{-1} \mathrm{HgCl}_{2}$ in $1 \% \mathrm{HNO}_{3}$ was used as the inorganic mercury source. The $\mathrm{pH}$ value of the reaction system was adjusted by $0.1 \mathrm{M} \mathrm{NaOH}$ and $0.1 \mathrm{M} \mathrm{H}_{2} \mathrm{SO}_{4}$, and determined using a $\mathrm{pH}$ meter (Hanna Instruments $\mathrm{pH} 211 \mathrm{C}$ with $\mathrm{HI}$ 1200B glass body combination $\mathrm{pH}$ electrode). The salinity of the solution was adjusted with $5 \mathrm{M} \mathrm{NaCl}$. The glass tubes were covered with aluminum foil to keep it dark and placed in a thermostatic bath to maintain a constant temperature.

Table 1. Experimental conditions of HPLC-UV-CV-AFS

\begin{tabular}{|c|c|}
\hline \multicolumn{2}{|l|}{ HPLC } \\
\hline Column & $\begin{array}{l}\text { Agilent Zorbax ODS column, } \\
4.6 \times 150 \mathrm{~mm}, 5 \mu \mathrm{m}\end{array}$ \\
\hline Mobile phase & $\begin{array}{l}10 \%(\mathrm{v} / \mathrm{v}) \mathrm{HCN} ; 60 \mathrm{mM} \\
\mathrm{CH}_{3} \mathrm{COONH}_{4} ; 0.01 \%(\mathrm{v} / \mathrm{v}) \\
\text { 2-mercaptoethanol }\end{array}$ \\
\hline $\begin{array}{l}\text { Flow rate of Mobile } \\
\text { phase }\end{array}$ & $1.0 \mathrm{ml} \mathrm{min}-1$ \\
\hline Sample injection volume & $20 \mu \mathrm{l}$ \\
\hline \multicolumn{2}{|l|}{ Hydride generation } \\
\hline Oxidant solution & $\begin{array}{l}0.5 \%(\mathrm{~m} / \mathrm{v}) \mathrm{K}_{2} \mathrm{~S}_{2} \mathrm{O}_{8} \text { in } 10 \% \\
(\mathrm{v} / \mathrm{v}) \mathrm{HCl}, 1.8 \mathrm{ml} \mathrm{min}^{-1}\end{array}$ \\
\hline Reducing solution & $\begin{array}{l}0.5 \%(\mathrm{~m} / \mathrm{v}) \mathrm{KBH}_{4}, 3.6 \mathrm{ml} \\
\mathrm{min}^{-1}\end{array}$ \\
\hline \multicolumn{2}{|l|}{ AFS } \\
\hline Lamp & $\begin{array}{l}\text { Hollow cathode mercury } \\
\text { lamp, } 253.7 \mathrm{~nm}\end{array}$ \\
\hline PMT voltage & $280 \mathrm{~V}$ \\
\hline Primary current & $40 \mathrm{~mA}$ \\
\hline Carrier gas & Argon, $500 \mathrm{ml} \mathrm{min}-1$ \\
\hline
\end{tabular}


Concentrations of the product in the reaction system were monitored during the reaction procedure for kinetic analysis.

\section{RESULTS AND DISCUSSION}

The chromatograms of standard substances were compared with those of the samples from the reaction system (Fig. 1). This demonstrated that water-soluble mercury species could be successfully separated and detected by the HPLC-UVCV AFS. As seen in Fig. 1, it could be judged that MMC is a water-soluble reaction product in the aqueous solution. This experimental result is consistent with that observed by Bertilsson and Craig. ${ }^{13,15}$

The effect of $\mathrm{pH}$ on the methylation reaction is depicted in Fig. 2. It could be clearly observed that the $\mathrm{pH}$ of the solution has a major effect on the methylation of inorganic $\mathrm{Hg}$ (II). Under strongly acidic conditions, a moderate amount of inorganic $\mathrm{Hg}$ (II) was methylated by methylcobalamin. With the increase of $\mathrm{pH}$, the concentration of MMC in the

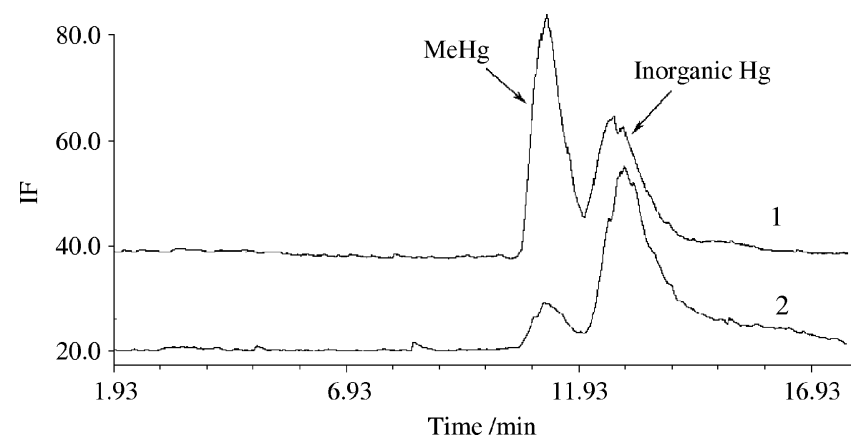

Figure 1. HPLC-UV-CV-AFS chromatograms of mercury species in water. 1, Standard substances; 2, sample from reaction system.

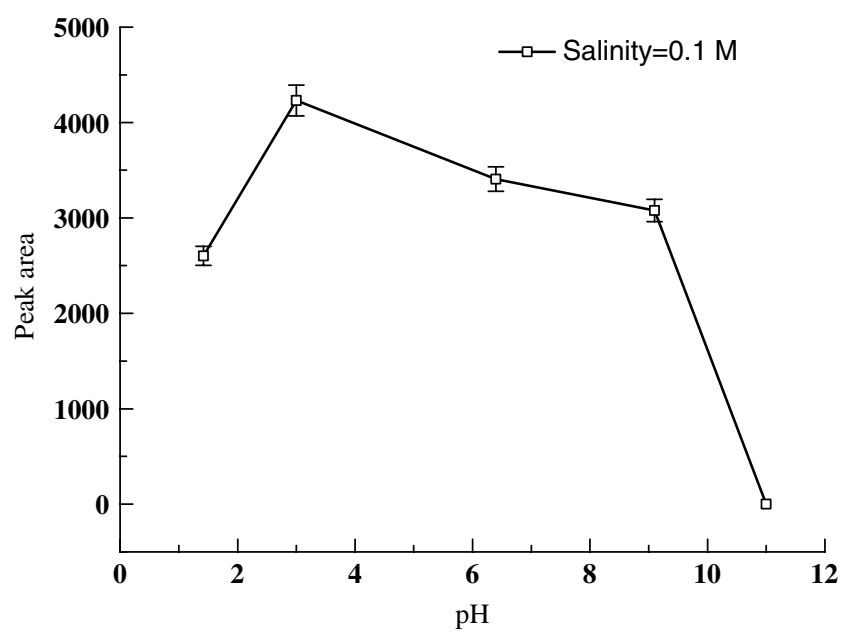

Figure 2. The effect of the $\mathrm{pH}$ on the methylation reaction. (Peak area refers to MMC detected by HPLC-UV-CV-AFS).

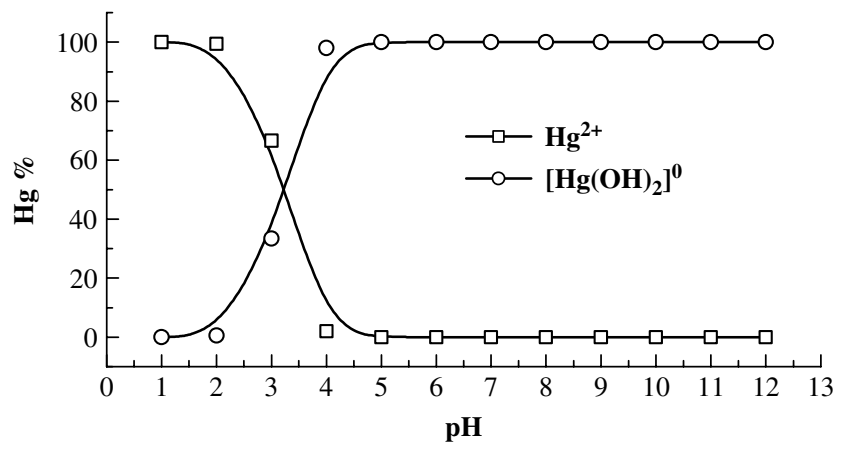

Figure 3. The relative amount of different inorganic mercury species vs $\mathrm{pH}$ [calculation from the complexing stability constant of $\mathrm{OH}^{-}$with $\mathrm{Hg}^{2+}$ using equation $\left.(1)^{16}\right]$.

reaction system peaked at $\mathrm{pH} 3$. Henceforth, the methylation yield of inorganic $\mathrm{Hg}$ (II) dropped with the increase in $\mathrm{pH}$. There are two probable explanations for the effect of $\mathrm{pH}$ on the methylation reaction. On one hand, it is due to inorganic $\mathrm{Hg}$ (II) complexing with $\mathrm{OH}^{-}$in the reaction solution. According to the complexing stability constant of $\mathrm{OH}^{-}$with $\mathrm{Hg}^{2+}$, the ratio between $\mathrm{Hg}^{2+}$ and $\left[\mathrm{Hg}(\mathrm{II})(\mathrm{OH})_{2}\right]^{0}$ in the solution is obtained from equation (1) and is shown in Fig. 3.

$$
\delta_{\mathrm{HgL}_{n}}=\frac{\beta_{n}[\mathrm{~L}]^{n}}{1+\sum_{i=1}^{n} \beta_{i}[\mathrm{~L}]^{i}}
$$

where $\mathrm{L}$ is the complexing ligand, $\beta$ is the complexing stability constant and $n$ is complexing level. ${ }^{16}$ On the other hand, methylcobalamin in aquatic solutions is subjected to an equilibrium between the 'base on' form (5,6-dimethylbenzimidazole coordinated to the cobalt atom), and the uncoordinated 'base off with $\mathrm{H}^{+\prime}$ form. ${ }^{17}$ The equilibrium is shown in equation (2).

$$
\text { Base on } \quad \text { Base off with } \mathrm{H}^{+}
$$

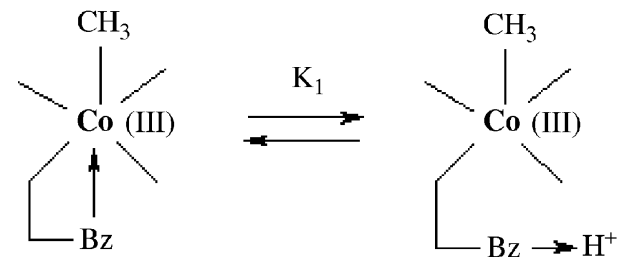

Different species of inorganic $\mathrm{Hg}$ (II) and methylcobalamin show different reactivities. In strongly acidic solutions, the main methylation pathway of inorganic $\mathrm{Hg}$ (II) would be the reaction between $\left[\mathrm{Hg}(\mathrm{II}) \mathrm{Cl}_{n}\right]^{2-n}$ and the 'base off with $\mathrm{H}^{+}$' form of methylcobalamin. However, a more complex system exists at $\mathrm{pH} 3$, which involves $\left[\mathrm{Hg}(\mathrm{II}) \mathrm{Cl}_{n}(\mathrm{OH})_{m}\right]^{2-n-m}$, 'base off with $\mathrm{H}^{+}$, and 'base on'. Under higher $\mathrm{pH}$ conditions, the only methylation reaction is between $\left[\mathrm{Hg}(\mathrm{II})(\mathrm{OH})_{2}\right]^{0}$ and the 'base on' form of methylcobalamin.

Appl. Organometal. Chem. 2007; 21: 462-467 
Since the salinity of aqueous solution is of great environmental interest, its effect on the methylation of $\mathrm{Hg}$ (II) was also investigated at two $\mathrm{pH}$ levels (Fig. 4). In our experiments, the range of the salinity was $0-1.0 \mathrm{M}$, which covers the salinity of most aquatic environments (the salinity of seawater $0.5 \mathrm{M}$ ). The salinity exerts a different influence on the methylation reaction under different $\mathrm{pH}$ conditions. In strongly acidic solutions, the yield of MMC decreased with the increase of the salinity, because of the different reactivity of $\mathrm{Hg}^{2+},[\mathrm{HgCl}]^{+}$, $\left[\mathrm{HgCl}_{2}\right]^{0},\left[\mathrm{HgCl}_{3}\right]^{-}$and $\left[\mathrm{HgCl}_{4}\right]^{2-}$ with methylcobalamin. The order of reactivity is as follows: $\mathrm{Hg}^{2+}>[\mathrm{HgCl}]^{+}>$ $\left[\mathrm{HgCl}_{2}\right]^{0}>\left[\mathrm{HgCl}_{3}\right]^{-}>\left[\mathrm{HgCl}_{4}\right]^{2-}$. A large amount of $\mathrm{Cl}^{-}$ would increase the electron density of $\mathrm{Hg}$ (II) and decrease the electrophilicity of $\mathrm{Hg}(\mathrm{II})$ towards the carbanion methyl group of methylcobalamin. Figure 5 shows relative amount of different inorganic mercury species at different salinity, which can be computed by equation (1) using the complexing stability constant of $\mathrm{Hg}^{2+}$ with $\mathrm{Cl}^{-}$listed in Table 2. At $\mathrm{pH} 5$, the concentration of MMC rose and quickly became constant with the increase of the salinity. The reason for this phenomenon is that $\mathrm{OH}^{-}$has stronger ability to complex with $\mathrm{Hg}^{2+}$ than $\mathrm{Cl}^{-}$. Two explanations for stronger complexing ability of $\mathrm{OH}^{-}$with $\mathrm{Hg}^{2+}$ than $\mathrm{Cl}^{-}$were proposed: (1) $\mathrm{OH}^{-}$has higher complexing stability constant with $\mathrm{Hg}^{2+}$ than $\mathrm{Cl}^{-}$(Table 2); (2) the nucleophilicity of $\mathrm{OH}^{-}$ is higher than that of $\mathrm{Cl}^{-}{ }^{18}$ Therefore, the increase in $\mathrm{Cl}^{-}$ influences only slightly the methylation of inorganic $\mathrm{Hg}$ (II) at $\mathrm{pH}$ 5.0. Celo et al. concluded that methylcobalamin was unlikely to methylate $\mathrm{Hg}$ (II) in moderately or highly saline environment. ${ }^{3}$ However, our results are inconsistent with above conclusion. In the range of salinity from 0 to $1.0 \mathrm{M}$, all inorganic $\mathrm{Hg}(\mathrm{II})$ can be methylated by methylcobalamin. In particular, the salinity has a slight influence on the high yield of MMC at $\mathrm{pH}$ 5.0, which is more environmentally relevant.

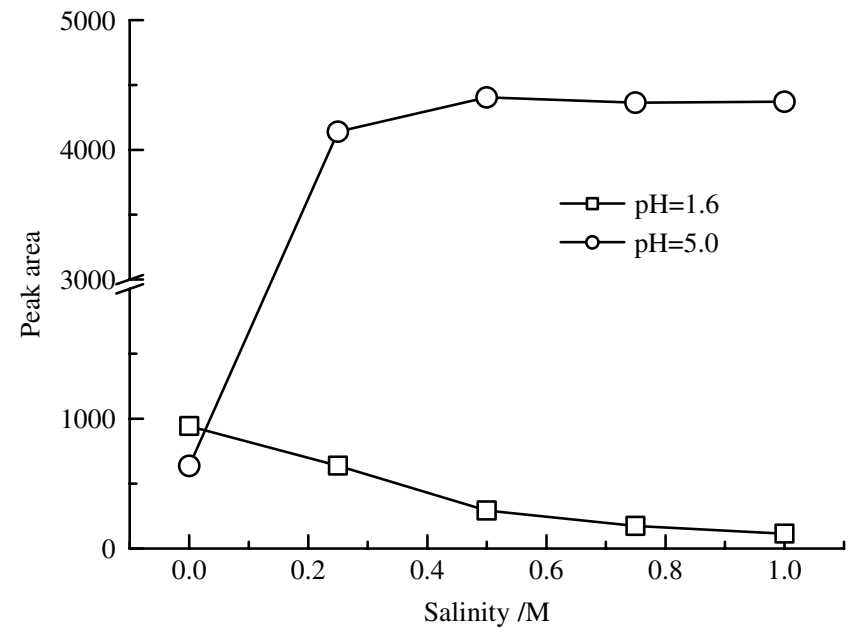

Figure 4. The effect of salinity on the methylation reaction.

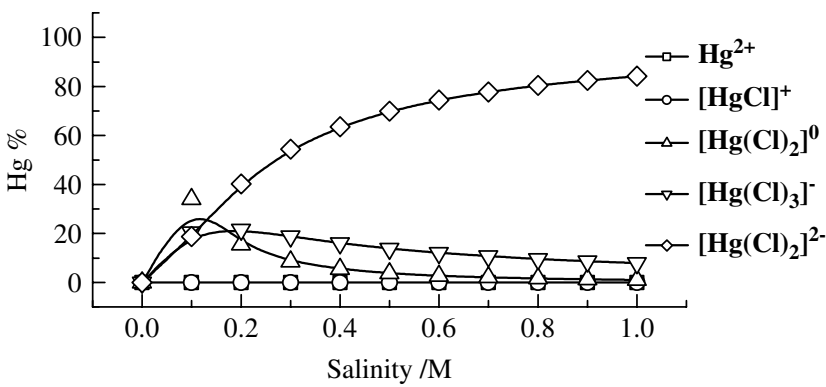

Figure 5. The relative amount of different inorganic mercury species vs salinity [calculation from the complexing stability constant of $\mathrm{Cl}^{-}$with $\mathrm{Hg}^{2+}$ using equation (1) $\left.{ }^{16}\right]$.

Table 2. Stability constant of $\mathrm{Hg}^{2+}$ complexing with $\mathrm{OH}^{-}$and $\mathrm{Cl}^{-}$

\begin{tabular}{lc}
\hline $\begin{array}{l}\text { Equilibrium } \\
\text { reaction }\end{array}$ & $\beta$ (complexing $^{16}$ \\
stability constant)
\end{tabular}

Complexing with $\mathrm{OH}^{-\mathrm{a}}$

$\mathrm{Hg}^{2+}+2 \mathrm{OH}^{-}=\left[\mathrm{Hg}(\mathrm{OH})_{2}\right]^{0}$

Complexing with $\mathrm{Cl}^{-\mathrm{b}}$

$\mathrm{Hg}^{2+}+\mathrm{Cl}^{-}=[\mathrm{HgCl}]^{+}$

$\mathrm{Hg}^{2+}+2 \mathrm{Cl}^{-}=\left[\mathrm{HgCl}_{2}\right]^{0}$

$\mathrm{Hg}^{2+}+3 \mathrm{Cl}^{-}=\left[\mathrm{HgCl}_{3}\right]^{-}$

14.07

$\mathrm{Hg}^{2+}+4 \mathrm{Cl}^{-}=\left[\mathrm{HgCl}_{4}\right]^{2-}$

a Ionic strength is 0.5 .

${ }^{\mathrm{b}}$ Ionic strength is 0.5 .

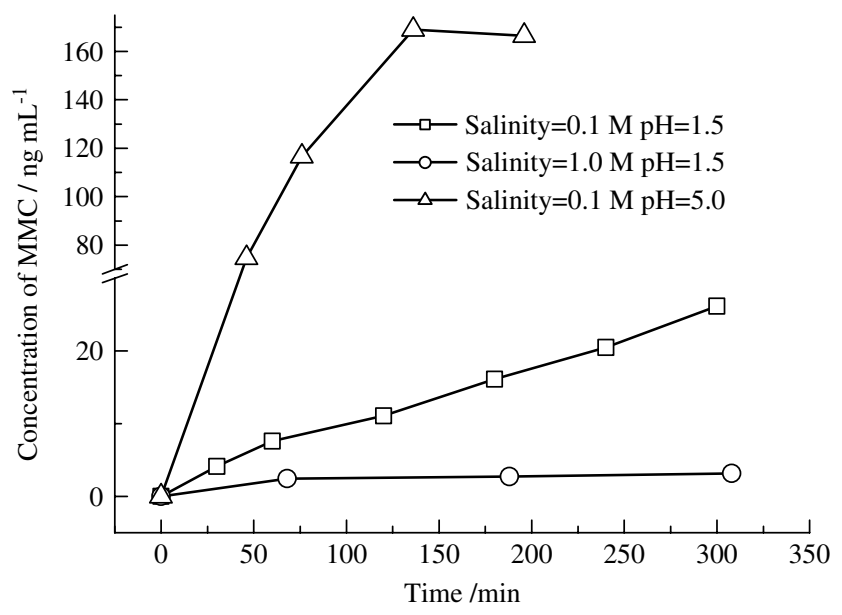

Figure 6. Formation of MMC vs. the time under different conditions.

Kinetic experiments were also performed under different conditions of salinity and $\mathrm{pH}$ (Fig. 6). It was found that both $\mathrm{pH}$ and salinity have strong influences on the methylation rate. In the solution of $\mathrm{pH} 5.0$, the rate of the methylation 
reaction was fast, and the yield of MMC was more than $50 \%$. The methylation reaction of inorganic $\mathrm{Hg}$ (II) reached equilibrium after $150 \mathrm{~min}$. However, under strongly acidic conditions, all methylation reactions of inorganic $\mathrm{Hg}$ (II) became slower and the yield of MMC was lower than that at pH 5.0.

A large excess of methylcobalamin over inorganic $\mathrm{Hg}$ (II) was designed in the kinetic experiments so that the concentration of methylcobalamin remained essentially constant in the methylation system. The methylation reaction can be considered as pseudo-first-order for $\mathrm{Hg}(\mathrm{II})$, i.e. $m=1$ because of the linear relationship between $\ln \left[\left(C_{0}-C\right) / C_{0}\right]$ and the reaction time, where $C_{0}$ is the initial concentration of inorganic $\mathrm{Hg}(\mathrm{II})$ and $\mathrm{C}$ is the concentration of $\mathrm{CH}_{3} \mathrm{Hg}$ in the methylation system. The results of the first order kinetic fit are visualized in Fig. 7. The high correlation coefficient ( $R=0.99$ ) corroborates the linear relationship. Thus, it could be deduced that this methylation reaction was first-order for inorganic $\mathrm{Hg}(\mathrm{II})$. The first-order reaction rates were 0.00612 and $0.000287 \mathrm{~min}^{-1}$ in the solution at $\mathrm{pH} 5.0$ and 1.5 , respectively.

The reaction mechanism for inorganic $\mathrm{Hg}(\mathrm{II})$ and methylcobalamin can be considered as a transfer of carbanion methyl group to the higher oxidized state of inorganic $\mathrm{Hg}$ (II). The inorganic $\mathrm{Hg}$ (II) acts as an electrophile, and heterolytic cleavage of the Co-C bond in methylcobalamin occurs. ${ }^{19}$ According to our experimental results, it is suggested that the methylation of inorganic $\mathrm{Hg}$ (II) by the methylcobalamin may occur in the absence of the enzyme. The schematic of this methylation reaction is presented in equation (3).

$$
\begin{aligned}
& {\left[\mathrm{Hg}(\mathrm{II}) \mathrm{Cl}_{n}(\mathrm{OH})_{m}\right]^{2-n-m}+\mathrm{CH}_{3} \mathrm{~B}_{12}(\mathrm{III}) \longrightarrow\left[\mathrm{CH}_{3} \mathrm{Hg}(\mathrm{II}) \mathrm{Cl}_{n}\right.} \\
& \left.(\mathrm{OH})_{m}\right]^{1-n-m}+\mathrm{B}_{12}
\end{aligned}
$$

In the reaction system, inorganic $\mathrm{Hg}$ (II) exists in the form $\left[\mathrm{Hg}(\mathrm{II}) \mathrm{Cl}_{n}(\mathrm{OH})_{m}\right]^{2-n-m}$, in which $\mathrm{Hg}^{2+}$ forms a complex with inorganic ligands such as $\mathrm{Cl}^{-}$and $\mathrm{OH}^{-}$.

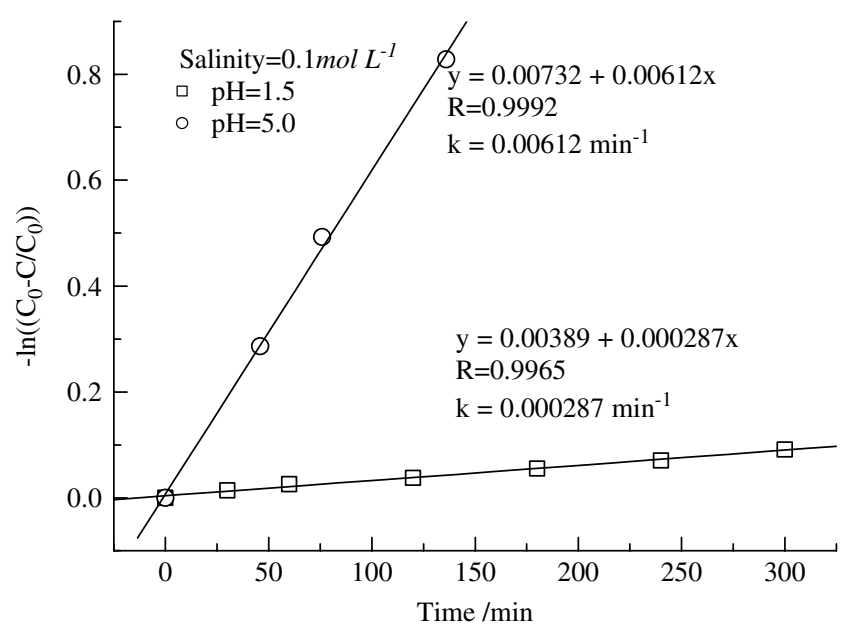

Figure 7. First-order rate plots at different $\mathrm{pH}$.
Base on<smiles>CC(C)(C)[Ge](C)(C)CC[Te]</smiles>

Base off with $\mathrm{Hg}$ (II)

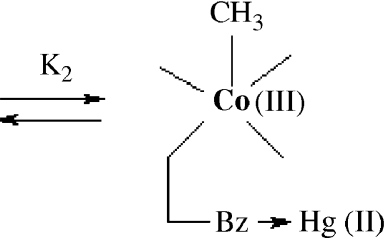

$\left[\mathrm{Hg}(\mathrm{II}) \mathrm{Cl}_{n}(\mathrm{OH})_{m}\right]^{2-n-m}$ acts as an electrophile would be available to coordinate with the nitrogen atom in the 5,6 dimethylbenzimidazole moiety of methylcobalamin. Thus, there is another equilibrium of methylcobalamin, shown in equation (4), in the aqueous solution besides that in equation (2). The methylation reaction may also take place between the 'base off with $\mathrm{Hg}(\mathrm{II})^{\prime}$ form and $\left[\mathrm{Hg}(\mathrm{II}) \mathrm{Cl}_{n}(\mathrm{OH})_{m}\right]^{2-n-m}$. However, the equilibrium in equation (4) is not the dominant equilibrium in relation to that in equation (2) due to low concentration of inorganic $\mathrm{Hg}(\mathrm{II})$. The reaction of the 'base on' form with $\left[\mathrm{Hg}(\mathrm{II}) \mathrm{Cl}_{n}(\mathrm{OH})_{m}\right]^{2-n-m}$ is, in this reaction system, the predominant pathway in producing MMC. It has been reported that the 'base on' form reacts with inorganic $\mathrm{Hg}$ (II) at least 1000 times faster than 'base off with $\mathrm{Hg}$ (II) $)^{\prime} .{ }^{20}$ It is widely accepted that the 'base on' form has higher activity than the 'base off' form [including 'base off with $\mathrm{H}^{+\prime}$ and 'base off with $\left.\mathrm{Hg}(\mathrm{II})^{\prime}\right]$. The difference in their reactivity is presumably due to the difference in electron density at the $\mathrm{Co}-\mathrm{C}$ bond where the 'base on' form has a greater electron density because of the coordination of the benzimidazole nitrogen in the sixth ligand site.

There are two kinds of anionic ligand in the reaction systems: $\mathrm{Cl}^{-}$and $\mathrm{OH}^{-}$, which complexes with $\mathrm{Hg}^{2+}$. However, the nucleophilicity of $\mathrm{OH}^{-}$is stronger than that of $\mathrm{Cl}^{-}, 18$ which is also demonstrated by the magnitude of the complexing stability constant with $\mathrm{Hg}^{2+}$. In $\left[\mathrm{Hg}(\mathrm{II}) \mathrm{Cl}_{n}(\mathrm{OH})_{m}\right]^{2-n-m}$, more complexing ligand and replacement of $\mathrm{Cl}^{-}$by $\mathrm{OH}^{-}$will reduce the electrophilicity of inorganic $\mathrm{Hg}(\mathrm{II})$. As a result, the effects of $\mathrm{pH}$ and salinity on the methylation reaction are due to the changes of electron density of the methyl donor and the electrophilicity of inorganic $\mathrm{Hg}$ (II). With the increase in $\mathrm{pH}$ from 1.0 to 3.0 , more $\mathrm{OH}^{-}$complexing with $\mathrm{Hg}$ (II) would reduce the nucleophilicity of inorganic $\mathrm{Hg}$ (II) and the reaction rate. However, the reaction rate still rise because of the increase of the 'base on' form which has higher reactivity than the 'base off' form. Base on this fact, it is easy to judge that $\mathrm{pH}$ dependency of the methylcobalamin is a dominant factor for methylation rate of inorganic $\mathrm{Hg}(\mathrm{II})$.

The kinetic experiments at two $\mathrm{pH}$ levels also explain that there are two entirely different reactions in different $\mathrm{pH}$ solutions because of their great difference in first order reaction rate. In the strongly acidic solution $(\mathrm{pH} 1.5)$, the methylation occurs between $\left[\mathrm{Hg}(\mathrm{II}) \mathrm{Cl}_{n}\right]^{2-n}$ and 'base off with $\mathrm{H}^{+\prime}$ form. However, $\left[\mathrm{Hg}(\mathrm{II})(\mathrm{OH})_{m}\right]^{2-m}$ is methylated by the 'base on' form in the reaction system at $\mathrm{pH} 5$. The methylation rate at $\mathrm{pH} 5.0$ is over 20 times faster than that at $\mathrm{pH} 1.5$. It 
validates the conclusion by DeSimone, ${ }^{20}$ which is that the 'base on' form has higher activity than the 'base off' form.

\section{CONCLUSION}

A sensitive HPLC-UV-CV-AFS method was applied in studying the methylation of inorganic $\mathrm{Hg}$ (II) by methylcobalamin in aqueous systems. This methylation reaction has been shown to occur even in the absence of the enzyme. It is proposed that inorganic $\mathrm{Hg}(\mathrm{II})$ acts as an electrophile and attack on methylcobalamin, resulting in the transfer of carbanion methyl group from methylcobalamin to the higher oxidized state of $\mathrm{Hg}$ (II). The salinity and $\mathrm{pH}$ of the reaction system influence this methylation reaction because of their effects on the species of the reactants. The salinity and the $\mathrm{pH}$ change the electron density of the methyl donor and the electrophilicity of the metal ions in the reaction system. The methylation reaction of inorganic $\mathrm{Hg}$ (II) with methylcobalamin is fast and first-order for $\mathrm{Hg}(\mathrm{II})$. This methylation reaction has been shown to be of importance in aquatic environments, even in the presence of $\mathrm{Cl}^{-}$, since it can still occur under high salinity conditions (salinity between 0.5 and $1.0 \mathrm{M}$ ).

\section{Acknowledgments}

This work was jointly supported by the National Natural Science Foundation of China (20477053), the National Basic Research Program of China (2003CB415001 and 2005CB422206) and Chinese Academic Sciences (KJCX2-SW-H06).

\section{REFERENCES}

1. Tesuo H, Hisamitsu N, Yoshitada Y, Takahiko S. Crit. Rev. Environ. Sci. Technol. 1995; 25: 45.
2. Jensen S, Jernelov A. Nature 1969; 223: 753; doi:10.1038/223753a0.

3. Celo V, Lean DRS, Scott SL. Sci. Total Environ. 2006; 368: 126; doi:10.1016/j.scitotenv.2005.09.043.

4. Weber JH. Chemosphere 1993; 26: 2063; doi:10.1016/00456535(93)90032-Z.

5. Hisamitsu N. Sci. Total Environ. 1982; 25: 133; doi:10.1016/00489697(82)90082-1.

6. Gilmour CC, Henry EA, Michell R. Environ. Sci. Technol. 1992; 26: 2281; doi: 10.1021/es00035a029.

7. King JK, Kostka JE, Frischer ME, Saunders FM. Appl. Environ. Microbiol. 2000; 66: 2430.

8. Akagi H, Fujita M, Sakagami Y. Eisei kagaku 1972; 18: 309.

9. Akagi H, Sakagami Y. Eisei kagaku 1972; 18: 358.

10. Cerrati G, Bernhard M, Weber JH. Appl. Organomet. Chem. 1992; 6: 587; doi:10.1002/aoc.590060705.

11. Wood JM, Kennedy FS, Rossen CG. Nature 1968; 220: 173; doi:10.1038/220173a0.

12. Choi SC, Bartha R. Appl. Environ. Microbiol. 1993; 59: 290.

13. Bertilsson L, Neujahr HY. Biochemistry 1971; 10: 2805; doi: 10.1021/bi00790a024.

14. Nobumasa I, Eiji S, Shoe-Kung P, Kiyoshi N, Jong-Yoon K, Kwan T, Ukita T. Science 1971; 172: 1248; doi: 10.1126/science.172.3989.1248.

15. Craig PJ, Morton SF. J. Organometall. Chem. 1978; 145: 79; doi: 10.1016/s0022-328x(00)84076-0.

16. Xu ML, Lai XX, Fan J, Zheng PL. Handbook of Analytical Chemistry. Science Press: Beijing, 1982; 621.

17. Pratt JM. Inorganic Chemistry of Vitamin B12. Academic Press: London, 1972; 44.

18. Xing QY, Xu RQ, Zhou ZH, Pei WW. Organic Chemistry. Higher Education Press: Beijing 1992; 137-144.

19. Ridley WP, Dizikes LJ, Wood JM. Science 1977; 197: 329; doi: 10.1126/science.877556.

20. DeSimone RE, Penley MW, Charboneau L, Smith SG, Wood JM, Hill HAO, Pratt JM, Ridsdale S, Williams RJP. Biochim. Biophys. Acta 1973; 304: 851; doi:10.1016/0304-4165(73)90232-8. 